\begin{tabular}{|l|l|l|}
\hline \multicolumn{2}{|c|}{ PublisherInfo } \\
\hline \hline PublisherName & $:$ & BioMed Central \\
\hline \hline PublisherLocation & $:$ & London \\
\hline \hline PublisherImprintName & $:$ & BioMed Central \\
\hline \hline
\end{tabular}

\title{
Downsizing the Paramecium genome
}

\begin{tabular}{|l|l|l||}
\hline \multicolumn{2}{|c|}{ ArticleInfo } \\
\hline \hline ArticleID & $:$ & 3826 \\
\hline \hline ArticleDOI & $:$ & $10.1186 /$ gb-spotlight-20001109-02 \\
\hline \hline ArticleCitationID & $:$ & spotlight-20001109-02 \\
\hline \hline ArticleSequenceNumber & $:$ & 263 \\
\hline \hline ArticleCategory & $:$ & Research news \\
\hline \hline ArticleFirstPage & $:$ & 1 \\
\hline \hline ArticleLastPage & $:$ & 2 \\
\hline \hline & & RegistrationDate : 2000-11-09 \\
ArticleHistory & $:$ & OnlineDate \\
\hline \hline ArticleCopyright & $:$ & BioMed Central Ltd2000-11-09 \\
\hline \hline ArticleGrants & $:$ & \\
\hline \hline ArticleContext & $:$ & 130591111 \\
\hline \hline
\end{tabular}




\section{Jonathan B Weitzman}

Email: jonathanweitzman@hotmail.com

The elimination of specific DNA elements is a common feature in the formation of a transcriptionally active macronucleus during the sexual reproduction of ciliated protozoa. The micronuclear DNA of Paramecium tetraurelia contains some 50,000 internal eliminated sequences (IES), each of which is flanked by TA dinucleotide repeats and inverted sequences. In the November Molecular and Cellular Biology $\mathrm{Ku}$ et al. describe an in vivo method to analyse IES excision (Mol Cell Biol 2000, 20:8390-8396). They injected DNA containing a 28 base pair IES and a drug-resistance gene into mated ciliate cells. They selected for transformants and assayed for excision by simple PCR amplification. Analysis of various deletions showed that flanking sequences are essential for excision, whereas mutations within the IES had no effect. This study reveals similarities between Paramecium and DNA excision events in Tetrahymena.

\section{References}

1. Genome downsizing during ciliate development: nuclear division of labor through chromosome restructuring.

2. Molecular and Cellular Biology, [http://intl-mcb.asm.org]

3. Programmed DNA deletions in Tetrahymena: mechanisms and implications. 